\title{
Whole blood exchange transfusion as a promising treatment of aluminium phosphide poisoning
}

\author{
Nasim Zamani ${ }^{1,2}$, Hossein Hassanian-Moghaddam ${ }^{1,2}$, and Sakine Ebrahimi ${ }^{3}$ \\ Department of Clinical Toxicology ${ }^{l}$, Social Determinants of Health Research Center ${ }^{2}$, Department of Internal \\ Medicine $e^{3}$ Loghman-Hakim Hospital, Shahid Beheshti University of Medical Sciences, Tehran, Iran
}

[Received in March 2018; Similarity Check in March 2018; Accepted in September 2018]

\begin{abstract}
A 37-year-old male was referred to us about one hour after deliberate ingestion of two 3-gram aluminium phosphide (ALP) tablets. Three hours after admission, his blood pressure dropped to $85 / 55 \mathrm{mmHg}$, his heart rate increased to $120 \mathrm{bpm}$, $\mathrm{O}_{2}$ saturation dropped to $82 \%$, and the electrocardiogram showed junctional rhythm. We started whole blood exchange, and gross haematuria and jaundice ensued. However, his blood pressure increased, arrhythmia resolved itself, and he was extubated two days after the transfusion was completed. He was sent home seven days after admission completely symptom-free. We believe this treatment may be successfully applied in ALP-poisoned patients.
\end{abstract}

KEY WORDS: arrhythmia; blood pressure; haematuria, icterus; junctional rhythm; extracorporeal techniques; toxicity

In some southern Asian countries pesticide poisonings account for over $50 \%$ of all poisonings, with fatality rates as high as $70 \%(1,2)$. Among them, aluminium phosphide (ALP) poisoning has been the number one cause of death over the last two decades, especially in Iran $(3,4)$. This cardiovascular toxin is even more common than cardiovascular drugs in overdosed patients admitted to intensive care units (ICUs) (5).

Although its fatality rates are as high as $70 \%$, there is no antidote for ALP toxicity (6). Several treatments have been suggested, the most aggressive of which are intraaortic balloon pump and extracorporeal membrane oxygenation (ECMO) $(7,8)$. However, such treatments are extremely invasive, need experienced people to perform them, and are not readily available.

The mechanism of ALP toxicity is non-competitive blockage of cytochrome $\mathrm{C}$ oxidase, which inhibits oxidative phosphorylation and cellular respiration while it activates peroxide radicals. Phosphine can also inhibit catalase and deplete glutathione, which, in turn, results in cellular wall and canal dysfunction (6). Zamani and Mehrpour (9) and Hassanian-Moghaddam et al. (10) pointed to the role of affected erythrocytes in the mechanism of toxicity and death in ALP poisoning and Zamani and Mehrpour were the first to suggest blood exchange as an approach to treating ALP poisoning (9).

Correspondence to: Hossein Hassanian-Moghaddam, Loghman-Hakim Hospital Poison Center, South Karegar Ave, Kamali St, Tehran, Iran, E-mail:hassanian@sbmu.ac.ir or hasanian2000@yahoo.com

\section{CASE REPORT}

A 37-year-old male was referred to us about an hour after deliberate ingestion of two 3-gram ALP tablets (containing $56 \%$ of ALP). He had a history of suicide attempt by cyanide. He mentioned that he had vomited five minutes after the ingestion of the tablets. On presentation his vital signs were normal and $\mathrm{O}_{2}$ saturation was $98 \%$. $\mathrm{CO}$ oximetry showed a $26 \% \mathrm{CO}$ content.

The patient was admitted to the medical toxicology ICU with the diagnosis of ALP poisoning. Since the patient had vomited and arrived late after ingestion, gastric decontamination was not done.

Almost three hours after admission, his blood pressure dropped to $85 / 55 \mathrm{mmHg}$, his heart rate increased to $120 \mathrm{bpm}$, and $\mathrm{O}_{2}$ saturation dropped to $82 \%$ with no response to conventional treatments (6). The electrocardiogram showed junctional rhythm. The patient was therefore intubated and put on our routine treatment including calcium gluconate, magnesium sulphate, vitamin E, $N$-acetyl cysteine, and glucose-insulin $(5,6,10)$.

According to the risk assessment flowchart of our centre, which is applied in case of suspected ALP ingestions, any carboxyhaemoglobin ( $\mathrm{SpCO}$ ) of $25 \%$ or more can lead to death irrespective of the clinical findings on presentation (11). The attending physician therefore decided that the patient required whole blood exchange and ordered haematology consult. The patient's next of kin gave written consent to exchange transfusion after having been fully informed about the fatal nature of the poisoning and the unknown effects of the treatment. Having secured 10 units of red blood cells (RBCs), 10 units of fresh frozen plasma (FFP), and 10 units of platelets, the haematologist started 
whole blood exchange transfusion. One RBC unit was given every $30 \mathrm{~min}$ and $500 \mathrm{~mL}$ of the affected blood released from another venous line, followed by administration of one unit of FFP and one unit of platelets. To prevent common complications of whole blood exchange including hypocalcaemia, hypoglycaemia, and hypo or hyperkalaemia, blood glucose and electrolytes were checked every four hours and administered if indicated. Prothrombin time (PT), international normalised ratio (INR), partial thromboplastin time (PTT), and complete blood count (CBC) were checked every six hours, and platelets were given when they dropped below 150,000 per microlitre.

The patient developed gross haematuria almost three hours into the transfusion, mandating a 12-hour pause in $\mathrm{RBC}$ administration. Instead, he received serum therapy, vesicular irrigation, four units of FFP, and five units of platelets. Throughout the pause, the patient remained symptom-free. One day after the exchange transfusion was started, he developed fever and started receiving leukocytefree blood transfusion.

The whole blood exchange transfusion, including the 12-hour pause, lasted almost $20 \mathrm{~h}$, after which time the patient's fever resolved itself. However, on the third day, the patient developed jaundice, with total and indirect bilirubin of 4.5 and $3.8 \mathrm{mg} \mathrm{dL}^{-1}$, respectively. During the exchange transfusion SpCO increased to $47 \%$ but gradually dropped to normal $48 \mathrm{~h}$ after the exchange was completed. Although the patient had difficulty receiving food by gavage at first (which was overcome with metoclopramide treatment), his blood pressure increased, the arrhythmia resolved itself, and he was extubated two days after the exchange was completed. He remained completely symptom-free, started oral feeding regimen one day later, and was sent home after psychiatric evaluation on the seventh day from admission. On discharge, all haematological lab tests were normal.

\section{DISCUSSION}

High level of $\mathrm{CO}$ in CO-oximetry, hypotension, and cardiac arrhythmia are all indicators of severe poisoning (11). Our patient developed severe complications even though he received anti-oxidant treatment. ECMO was not available, and we thought we needed to do something to stop their progression before it was too late.

In 2012, Zamani and Mehrpour (9) suggested that glucose-6-phosphate dehydrogenase G6PD deficiency could have a protective role in ALP poisoning, as it leads to the breakdown or RBCs affected by oxidative stress and extra-mitochondrial release of free oxygen radicals in ALP poisoning. Therefore, they suggested, removing the affected RBCs with whole blood exchange be beneficial for ALPpoisoned patients.

A study in rats showed that G6PD deficiency, induced by 6 -aminonicotinamide, had a significant protective effect on the hepatocytes (12). A similar study showed that fresh red blood cell transfusion improved metabolic acidosis and increased the survival of ALP-poisoned rats (13). This led us to assume that the elimination of damaged RBCs by any method could improve treatment outcome.

Although the exchange transfusion in our patient was associated with haemolysis, jaundice, fever, and haematuria, we believe that it saved his life, as no other treatment than conservative anti-oxidant management was available. Haematuria developed almost three hours into the exchange transfusion. Having ruled out the ABO incompatibility reactions, we believe that this acute haemolytic transfusion reaction is related to incompatibility reactions to minor antibodies.

Although the exact mechanism of phosphine toxicity remains unclear, it has been suggested to inhibit cytochrome-C oxidase in platelets, as well (14). Therefore, whole blood exchange may be a better treatment than RBC exchange. Considering the $30-70 \%$ death rate of ALP poisoning (6) and less than $10 \%$ death risk of blood exchange (15), we believe that this treatment is reasonable in high-risk patients. Further investigation is needed to test this hypothesis.

Even though we could not test our patient for G6PD deficiency, because this test was not available at our centre, we believe this does not undermine our findings, because G6PD deficiency would not have affected the outcome of whole blood exchange. Our search across Google Scholar, Scopus, and PubMed, did not produce any other article suggesting the similar approach, and we hope that future studies will bring more answers about this approach to managing ALP poisoning. In the meanwhile, elimination of free oxygen radicals and affected RBCs with whole blood exchange transfusion may save a few more lives.

\section{Acknowledgements}

This case is the first recruited case of a pilot in Shahid Beheshti University of Medical Sciences (grant no. 136852018). We would like to thank our patient for giving informed consent (in writing) to the publication of this case.

\section{Conflict of interest}

None to declare.

\section{REFERENCES}

1. Eddleston M, Karalliedde L, Buckley N, Fernando R, Hutchinson G, Isbister G, Konradsen F, Murray D, Piola JC, Senanayake N, Sheriff R, Singh S, Siwach SB, Smit L. Pesticide poisoning in the developing world - a minimum pesticides list. Lancet 2002;360:1163-7. doi: 10.1016/S01406736(02)11204-9

2. Eddleston M. Patterns and problems of deliberate selfpoisoning in the developing world. QJM-Int J Med 2000;93:715-31. doi: 10.1093/qjmed/93.11.715 
3. Hassanian-Moghaddam H, Zamani N, Rahimi M, Shadnia S, Pajoumand A, Sarjami S. Acute adult and adolescent poisoning in Tehran, Iran; the epidemiologic trend between 2006 and 2011. Arch Iran Med 2014;17:534-8. doi: 014178/ AIM.003

4. Hassanian-Moghaddam H, Pajoumand A. Two years epidemiological survey of Aluminium Phosphide poisoning in Tehran. Iran J Toxicol 2007;1:35-9.

5. Hassanian-Moghaddam H, Amiri H, Zamani N, Rahimi M, Shadnia S, Taherkhani M. QT dispersion and prognostication of the outcome in acute cardiotoxicities: a comparison with SAPS II and APACHE II scoring systems. Cardiovasc Toxicol 2014;14:129-33. doi: 10.1007/s12012-013-9236-9

6. Hashemi-Domeneh B, Zamani N, Hassanian-Moghaddam H, Rahimi M, Shadnia S, Erfantalab P, Ostadi A. A review of aluminium phosphide poisoning and a flowchart to treat it. Arh Hig Rada Toksikol 2016;67:183-93. doi: 10.1515/ aiht-2016-67-2784

7. Hassanian-Moghaddam H, Zamani N, Rahimi M, Hajesmaeili M, Taherkhani M, Sadeghi R. Successful treatment of aluminium phosphide poisoning by extracorporeal membrane oxygenation. Basic Clin Pharmacol 2016;118:243-6. doi: 10.1111/bcpt.12481

8. Mehrpour O, Amouzeshi A, Dadpour B, Oghabian Z, Zamani N, Amini S, Hoffman RS. Successful treatment of cardiogenic shock with an intraaortic balloon pump following aluminium phosphide poisoning. Arh Hig Rada Toksikol 2014;65:1216. doi: 10.2478/10004-1254-65-2014-2393
9. Zamani N, Mehrpour O. Protective role of G6PD deficiency in poisoning by aluminum phosphide; are there possible new treatments? Eur Rev Med Pharmacol Sci 2013;17:994-5. PMID: 23640450

10. Hassanian-Moghaddam H, Zamani N. Therapeutic role of hyperinsulinemia/euglycemia in aluminum phosphide poisoning. Medicine 2016;95:e4349. doi: 10.1097/ MD.0000000000004349

11. Mashayekhian M, Hassanian-Moghaddam H, Rahimi M, Zamani N, Aghabiklooei A, Shadnia S. Elevated carboxyhaemoglobin concentrations by pulse CO-oximetry is associated with severe aluminium phosphide poisoning. Basic Clin Pharmacol 2016;119:322-9. doi: 10.1111/ bcpt.12571

12. Salimi A, Paeezi M, Yousefsani BS, Shadnia S, HassanianMoghaddam H, Zamani N, Pourahmad J. Inhibition of glucose-6-phosphate dehydrogenase protects hepatocytes from aluminum phosphide-induced toxicity. Pestic Biochem Phys 2017;143:141-6. doi: 10.1016/j.pestbp.2017.08.005

13. Rahimi N, Abdolghaffari AH, Partoazar A, Javadian N, Dehpour T, Mani AR, Dehpour AR. Fresh red blood cells transfusion protects against aluminum phosphide-induced metabolic acidosis and mortality in rats. PLoS One 2018;13(3):e0193991. doi: 10.1371/journal.pone.0193991

14. Singh S, Bhalla A, Verma SK, Kaur A, Gill K. Cytochrome-c oxidase inhibition in 26 aluminum phosphide poisoned patients. Clin Toxicol 2006;44:155-8. PMID: 16615671

15. Aylor WC. Mortality and morbidity of exchange transfusion. Can Med Assoc J 1962;87:1267-70. PMID: 20327333

\section{Zamjena pune krvi kao obećavajući način liječenja otrovanja aluminijevim fosfidom}

Muškarac star 37 godina primljen je u naš centar za otrovanja približno jedan sat nakon što je namjerno progutao dvije 3 -gramske tablete aluminijeva fosfida. Tri sata poslije krvni mu je tlak pao na $85 / 55 \mathrm{mmHg}$, broj otkucaja srca porastao na 120 u minuti, a zasićenje kisikom palo na $82 \%$. Nije odgovarao na konvencionalno liječenje. Na elektrokardiogramu se vidio nodalni ritam. Započet je postupak zamjene pune krvi, što je dovelo do pojave krvi u mokraći i do žutice. Krvni je tlak nakon postupka porastao, aritmija je prestala, a pacijent je ekstubiran dva dana nakon svršetka zamjene krvi. Otpušten je kući bez ikakvih simptoma sedam dana nakon prijema. Vjerujemo da bi ovakav način obrade mogao biti uspješan u liječenju otrovanja aluminijevim fosfidom. 